\title{
Methods of Verbalization of Events in Contemporary Russian Retro Detective Fiction
}

\author{
Innara A. Guseinova* \\ Moscow State Linguistic University \\ 38 Ostozhenka Str., Moscow, 119034, Russia
}

Received 07.09.2016, received in revised form 15.09.2016, accepted 03.10.2016

The present article is dedicated to investigation of contemporary Russian retro detective fiction. The author notes the specifics of retro detective fiction, including its scenario quality, its capability of transformation, and the presence of creative potential. To re-create past events retro detective fiction uses a definite selection of linguistic means, above all precedent entities, including precedent names and phenomena, as well as lexical items that have gone out of use. As a result of their complex application, the author of retro detective fiction exerts a cognitive, pragmatic impact on the reader and thus stimulates the emotional and intellectual working of the cognitive system of the mass recipient.

Keywords: genre, text, global context, retro detective fiction, retro literary discourse, historic events, precedent name.

DOI: 10.17516/1997-1370-2016-9-10-2427-2435.

Research area: art history.

This article is devoted to retro detective fiction - a popular genre of literary discourse that in large measure today defines and forms the contemporary reader's value relation to the cultural and historical past. In our analysis of methods for the verbalization of events in contemporary Russian historical detective fiction we have relied on three key elements that form any variety of discourse: the global context, the text, and the concrete event described in the text. These elements support the genre's discourse stability, which ensures its functioning among other literary genres.

Our choice in favor of retro detective fiction is not accidental, but rather is determined by the unusual popularity of the given genre with various groups of readers, thus providing a stimulus for the analysis of the retrodetective. The stability and popularity of the given genre are determined by the following characteristics that we have found in the course of analyzing contemporary Russian retro detective fiction, namely:

Its scenario quality, which permits the adaptation of the retrodetective to the communication channel for its distribution (books, television serials, artistic films, comics, etc.);

Its capability of transformation, which ensures its stability in various types of

(C) Siberian Federal University. All rights reserved

* Corresponding author E-mail address: guseynova@linguanet.ru 
environment and in correspondence to the tastes and preferences of the target audience;

The presence of creative potential, which forms the basis for a variety of readings and interpretations.

We will therefore dwell on these key discourse components of contemporary Russian retro detective fiction.

\section{Characteristics of the global context}

The widening of value systems as part of the expansion of secondary, largely material values leads to the fact that cultural heritage is compelled to "materialize" itself, i. e. constantly show its immaterial significance, which is very complex in the conditions of market relations that place buysell "object" values above all - objects of consumer demand, of basic necessity and of everyday existence. In this relation culturetainment, not infrequently denoted by contemporary scholars as a «deformed word and terrible phenomenon», ${ }^{1}$ is on the one hand determinative for the diffusion of cultural facts in the conditions of globalism, and on the other hand a preservation of national cultural distinctiveness. For the sake of fairness it should be said that culturetainment today infiltrates the entire humanistic space, beginning from the organization of museum projects or specific exhibits, performances, presentations, biennales, etc., with the goal of creating for specific cities a renown as theatrical, artistic or, for example, literary capitals. In the given case it is the technology that allows one to approach culture from the positions of a market economy. In regards to culturetainment it also seems to us appropriate to turn at the same time to such a very contemporary and widely used term as «brand». We share the point of view of contemporary researchers of this phenomenon who define it as an essence semiotic in its quality; that is, brand «is first and foremost a sign of a definite sort and, like any sign, it links the material and ideal worlds-but which in addition to this possesses specific properties that separate it from a multitude of

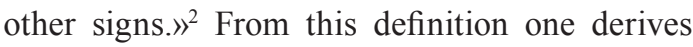
the trinary or threefold nature of brand: 1) the name of the brand; 2) the company-producer; 3) the meaning of the brand. Thus, precisely in the content of the brand are contained those specific properties that, in essence, distinguish it from a commercial name that is not a brand». ${ }^{3}$

From the above context we can affirm that the retro historical component is well placed for mastery of the cultural space of the book market and thus well placed for becoming a brand, inasmuch as it possesses all the attributes of the trinary nature mentioned earlier, and its content as a semiotic sign undoubtedly possesses the necessary distinctiveness for its promotion in the book market - as we will attempt to explain below.

In the first place, the turning to the historical past, the recreation of atmosphere in the retro style facilitates the attraction of attention to the cultural component of contemporary life and also the formation both of individual life spaces and of the cultural space of entire social groups (sotsium), proposing in the process numerous variants for the construction of an environment of habitation in the broad sense of the term locus.

Secondly, retro permits the contemporary person to assess events of the past, to understand the sources of the present, to interpret contemporaneity and to exert influence on the formation of humanistic space. We will note the not unimportant circumstance that extends preference to accessible sources that one can find either in the family library or in the most widespread informational communicative resources. In this sense retrodetective fiction is a source of cultural-historical information.

Thirdly, retro allows the ordinary person to turn into a creator--a maker of social and 
virtual spaces in which his presence brings him satisfaction and allows him to preserve a cultural continuity that comes forth as a connecting link with future generations.

In the fourth place, we share, in the proper context, the aforementioned slogan of George Orwell ${ }^{4}$ to the effect that «who controls the past controls the future; who controls the present controls the past.. ${ }^{5}$, The contemporary and the present today are compelled to respond at a minimum to two challenges--postmodernism and informatization.

We will remind that the postmodernist challenge proposes the review of traditional value and philosophical systems. As applied to the retro component the given situation, intensified by linguistic concepts, leads to a treatment of the past not as a historical event, but as a novel (for example, retrodetective fiction, the science fiction novel, etc.). Furthermore, the historical component in detective fiction cannot be subverted on the strength of their verification specifics. From the point of view of any science, that fact bears witness to the presence of a certain subjective principle, inasmuch as historical events in chronicles or narratives and other historical documents are written by people, and not infrequently from the words of other people--representatives of their ethnosocial group and of a defined epoch. Informatization in its turn secures for the person access to practically any data, both verified and in need of supplemental checking. Every reader or user of the virtual network has the possibility to choose that information which is for him the most acceptable. As a result of the capacity for multiple interpretations the retro component acquires properties characteristic of artistic invention, distancing itself from the real historico-cultural context. For the imparting of verisimilitude to retro, the author calls forth a fund of encyclopedic and mythological knowledge, thus supporting a balance between the past and present, historical truth and invention.

In the fifth place the retro component, located at the meeting point of the informational and the entertainment approach, is transformed as a result of the intellectual efforts of the author into a hybrid that can be considered in a broad sense as the infortainment industry. But «in order for entertainment to be qualitative someone must excavate in archives interesting facts, write scholarly books on the basis of which myths, legends, and historical reconstructions can later be created."

In the center of the reader's attention of the retrodetective is the history of the everyday life of the main hero or the evolution of the consciousness of the basic personage, placed in specific extreme situations that are typical for the described historical epoch. Thus, without claims to strict scholarly or historical verisimilitude the author presents to the curious reader an acquaintance with the past that permits him to create imagined worlds and construct entire mental spaces.

\section{Characteristics of Retro Detective Fiction}

In analyzing contemporary retro detective fiction from genre perspectives, we will note that today there are around forty Russian authors who work in the genre, a fact that testifies to the dynamic development of this direction in literary discourse. Today there is an intensive process of elaboration of the typology of the detective genre, as is witnessed by the rise of new detective series. Among accepted designations of detective fiction are psychological, ironic, fantastic, political, espionage, historical and others.

In the first place it should be noted that retro detective fiction describes events of a definite cultural-historical period. If Boris Akunin gives preference to events that occurred at the turn of 
the $20^{\text {th }}$ century, D. M. Truskinovskaia presents retro phenomenon on the basis of material from $17^{\text {th }}$-century Russia. Furthermore, authors of retrodetective novels do not tread upon the interests of authors who cultivate other temporal historical periods - apparently from ethical considerations.

In the second place, in retro detective fiction events occur in various regions of Russia. If previously the large capital cities of St. Petersburg and Moscow were the basic places in which events unfolded, in the present the Russian "boondocks" are now represented in novels. Furthermore, these novels describe not only cities in the process of industrialization, but also villages and hamlets, district towns and rural areas.

In the third place, retro detective fiction preserves all the signs of detective fiction, which do not allow the reader to confuse it with the historical novel or chronicles or autobiographical descriptions, despite the similarity and proximity if the mentioned literary genres.

In the fourth place the lingual means used in the creation of the phenomenon of retro fiction bear a regular character that permits the training of the reader in an adequate perception of the culturo-historical material, thus avoiding the loss of the reader's interest.

Traditionally detective fiction (from the Latin detego - I uncover, I expose) describes a certain puzzling event, the solving of which is accompanied by an elucidation of circumstances that have a relation to the occurrences. The central concept of detective fiction is crime. All the characters of the detective novel can provisionally be divided into several groups: 1) the person pursuing the investigation, for example, the sleuth, his assistant, a consultant; the detective, the amateur sleuth, etc.; 2) the person who has committed the crime, i. e. the criminal; 3 ) the victim of the crime, or the one enduring it. The elucidation of the circumstances requires the supplementary involvement of characters, in particular witnesses and suspects. The "retro" component serves as the designation of all that is old-fashioned, reproducing old times or the past. On that basis, works of Russian detective fiction whose action occurs on the territory of Russia before the 1917 revolution can be attributed to retro detective fiction.

In regard to retro detective fiction, the aforesaid can be concretized in the following manner: 1) detective fiction frequently immerses the reader in the near and distant past; 2) in the center of the plot stands a puzzling phenomenon accompanied by the ruminations and encounters with various people who have a direct or oblique relation to the puzzling event; 3) the description in the detective plot bears a production character that allows the conversion of the work into a scenario suitable for a theatrical, cinematic or computer rendition. In addition we will note that many detective histories by contemporary Russian authors can provisionally be divided into three large groups according to their orientation: 1) works that take into consideration the distinctiveness and national particulars of the Russian character; 2) works oriented toward the recreation of cultural-historical local color; 3) works encompassing both a national-cultural particularity as well as a historical context. Often such publications only partially correspond to an elevated artistic style and answer to the taste of an intellectual milieu; however, they represent an experimental literature directed toward the recreation of mutual ties between the past and contemporaneity. In this light the contemporary detective genre facilitates the conceptualization of a spectrum of values playing a determining role in the past, and also a return to and popularization of value orientations that existed earlier.

In describing Russian detective fiction it is appropriate to distinguish those works that are "authentic," i. e. that were written by authors 
in preceding centuries and which books found their worthy place in literature as information sources from which contemporary authors can draw authentic information, and contemporary detective fiction aspiring to strengthen the position of the detective genre in literary discourse.

\section{Means of verbalization of events in contemporary Russian retro detective fiction}

The growing interest of scholars in the retro component is to a great degree determined by the functions of contemporary literature directed toward the realization of a cognitive-pragmatic impact. Retro fiction assumes into itself phenomena that are signifiers for the nationalcultural society. In affirmation of this thesis we will introduce concrete examples that symbolize the epoch or, more narrowly, the time in which the events unfold.

The attraction of the attention of the mass reader requires an unanticipated move. Its realization utilizes among much else precedent entities. ${ }^{7}$ that in the texts analyzed by us often function in the form of precedent phenomena or, in a more narrow sense, in the form of precedent names. For an analysis of retro detective fiction it is an essential fact that precedent names are capable of forming a referential chain, and also of forming associative series with the reader, thus ensuring in retro detective fiction a continuity between the past and contemporaneity.

Let us turn to a concrete example that is presented in the form of dialog in the retro detective fiction of V. Danilin. The event unfolds in a book shop where the main characters' center of attention is A. Khvolson's book Among the Flowers, which was popular among Russian readers at the end of the $19^{\text {th }}$ century. Undoubtedly, a contemporary reader will hardly remember that the given writer, Anna Khvolson, was also the author of the book The Kingdom of the Little Ones.
The adventures of Murzilka and the wee forest people, in which are "described the journeys of elves with amusing names - Murzilka, Znaika, Neznaika". The author of the retro detective justifiably assumes that the contemporary reader will not always have encyclopedic knowledge and therefore introduces into the dialog the following passage which more precisely characterizes the work of the mentioned writer: "Anna Khvolson" is perhaps not the most accomplished writer, but her books are very good. And I will tell you, my young friend, that to describe elves as if they were real is a task of no small difficulty. For some reason it seems to me that Murzilka, Znaika and Neznaika will live on the pages of books for a very long time". ${ }^{10}$

Let us provide another example, where the retro detective author V. Danilin introduces as the main character investigating a puzzling crime in a Russian backwater a certain Vladimir Ulyanov, ${ }^{11}$ an exiled student excluded from the university and kept under covert police surveillance. Undoubtedly, the name V. Ulyanov is familiar to the Russian reader. Performing as a sort of attractor, the name gives rise to various associations, but for all members of the national cultural society, the given name in itself is familiar and connected with a definite historical epoch and events important for every member of the Russian-language ethnosocial group. For the curious reader the retro detective author introduces episodes described, for example, in $19^{\text {th }}$-century newspapers. In his novel Danilin describes an episode in which two main characters - amateur detectives make their way to visit Doctor Gribov, who happened to bring to consciousness a "failed suicide. A young man who had suffered from Amour's arrows." 12 With the mention of the name Aleksei Peshkov the reader is sent to a note in which A. Peshkov in free translation quotes H. Heine comparing love with a tooth 
ache (cf. Zahnschmerz): "I cannot live with a toothache in the heart". ${ }^{13}$

Precedent entities facilitate an interaction arising between the author and the reader, with the role of stimulus often performed by a precedent name, while the emotional and intellectual efforts of the reader enable him to recreate a cultural-historical context that ensures an adequate reading of the text, its understanding and interpretation.

Such devices are found among various authors of the given genre. For example, the main character in Nikolai Filatov's retro detective novel The Last Shot of the Court Chamberlain ${ }^{14}$ is Fedor Ivanovich Tiutchev, best known to a wide circle of readers as a poet and translator thanks to whom $19^{\text {th }}$-century Russian readers could become acquainted with the work of famous German classics such as Heinrich Heine and others. Tiutchev's cultural and enlightenment activity opened to the Russian reader new foreign literary works, while at the same time the foreign reader could learn about cultural, political and economic events in Russia thanks to the essays and articles published by Tiutchev in the German and French press. However, from the aforementioned novel the Russian, i.e. contemporary, reader will simultaneously learn that Tiutchev was a brilliant diplomat who fulfilled various extraordinary assignments for the foreign ministry; cf. "Indeed, Fedor Tiutchev turned up in Munich entirely due to the protection of an old family friend, the one-armed veteran of the Napoleonic wars Count Aleksandr Ivanovich Osterman-Tolstoi. Having taken a look at the young provincial secretary who had just entered the foreign ministry, the count recommended him to the position of extraordinary official in the Russian mission to the Bavarian court". ${ }^{15}$

An indubitable service of the retro detective author also occurs through passages in which events of the past share much in common with contemporary events. First and foremost we are speaking about the global political context as broadcast today by contemporary mass media; cf. "Some even demanded the Moldavia and Wallachia, ${ }^{16}$ the populations of which have one and the same origins, speak one and the same language and follow identical interests, should merge into one state! Moreover, they have dreamed of the creation of a great Rumanian fatherland by way of joining to it all its provinces that found themselves in the hands of Austria and Russia Transylvania, Bukovina, Bessarabia..." ${ }^{\prime 17}$ We will not pose for ourselves the task of commenting on current political events of a geopolitical character; however, we are introducing quotes that are intriguing for the contemporary reader and bear witness to the intransient significance of certain events for contemporary politics; cf. "The documents that Tiutchev now saw before himself bore witness to attempts by British and Turkish secret services to establish a link with the rebellious Caucasian Iman Shamil, who managed from numerous minor Dagestan and Chechen possessions riven by feudal civil conflicts and internal contradictions to create a unified state in the mountains of the northeastern Caucasus. ${ }^{18}$

Certain episodes from the past convey quite precisely the collisions occurring in contemporary European space; cf. "It was possible to imagine any sort of stupidity about the victories of the Greeks and launch them into play - everything was believed that served as food for rumors and exaggerations. However, in any case opinion very often split: some rejoiced in the successes of the Greeks, while others cursed the Greeks, who had destroyed the fat life of the boyars in the Danube principalities. $^{19}$

The attentive reader might have doubts about the veracity of the factual material published in retro detective fiction. Such doubts are dispersed by editions of the type of the Soviet historical encyclopedia, or by a reference to well-known 
authors of historical novels written on the basis of real historical events relying on chronicles, archival documents or historical information; on biographical editions, on works of literary history, and also publications in the $19^{\text {th }}$-century press, etc. (Ivan Aksakov, Valentin Pikul. Vadim Kozhinov, et al.).

Socio-economic problems relevant to the contemporary reader are also not left without attention in retro detective fiction; cf. "Wherever you look, everywhere there is turmoil, disorder, state theft, bribes. The sovereign has traveled through all Russia, and everywhere it is one and the same, and on the periphery it is even worse than in the center. And say, where are a sufficient quantity of officials going to come from who are diligent, precise, industrious, willing to immerse themselves in the details of service - and in addition would show genuine care in the spending of state resources?"20

The second method for recreating events we will provisionally designate with the lexeme "accrual". Knowledge of everyday life and historical facts "accrues" in the basic telling of the story, which allows one to gradually come to know the historical background. For example, in one of the dialogs between the main character and a cabbie there is a discussion about the naming of a street: “'Do we go along Chertolskaya?' he growled at last. 'How do you mean Chertolskaya, sir?' 'There is no more Chertolskaya,' Semeika mused. 'It is Prechistenka. The Sovereign commanded that it be so called. From my birth they used not to change the name of a street in Moscow,' objected the cabbie. It was Chertolye, and it will remain Chertolye.' 'So the Sovereign should go to church service at Novodevichii Convent, to the Cathedral of the Most Pure Smolensk Mother of God, and all along the way they will profanely think of the devil?' Semeika asked. [The word play is based on the root "chert," or devil," and "prechistenka," or "most pure".] 'Look, sir, they will drag you to the State Administration! There they will teach you that the street is called Prechistenskaya!"'21

From retro detective fiction it is possible to draw much useful information concerning the order of everyday life (in Moscow, for example) that is included in the basic plot line; cf. "Moscow houses were built in one manner. Perhaps some of the rich boyars and princes had amazing objects furniture from Poland, ceilings with painted stars, pounds of German clocks with silver weights and chimes - but the way of life for the simple man was thoroughly familiar to the stablemen. They thoroughly looked over basements and upper spaces, and made the rounds of attics, and closets, and cubby holes ..."22 Let us remind that the word "basement" [podklet] designated the lower - ground or half basement - level of a city-dweller's house, which had a separate entrance and was used primarily for household needs. At the same time it should be noted that the tradition of painting ceilings with stars is now very fashionable, as is the acquisition of foreign furniture. These facts also serve to underline the links between the past and present, thus keeping the reader at the boundary of the real and fictional worlds.

The third method permitting the recreation of the past is the use of words that have gone out of use. Not infrequently in descriptions of a character's appearance the author of retro detective fiction will turn to epithets that have gone out of active use or that have a narrow sphere of application; cf. "The former agent was dressed in a white calico shirt with a skewed collar and smoky velvet trousers. ${ }^{23}$ The given device is also used in the description of everyday details, for example, pieces of furniture or other interior objects; cf. "Excuse the disorder, gentlemen," said Evgenii Aleksandrovich with a constrained voice and lowered himself on the faille settee that stood near the buffet, a piece of furniture 
that was entirely out of place here." ${ }^{24}$ Not every reader will remember that the word "calico" is understood as a thin cotton twill or huckaback that was widespread in the middle and end of the nineteenth century, and faille is a thick fabric with small crosswise ribs; however, the use of the given lexemes serves the reader as a signal that the events are unfolding not now but in the past. The author of retro detective fiction does not tire the reader with ponderous words, the sense of which might not be clear to everyone, but he gives commentary that refines the designation, for example, a settee, cf. "a piece of furniture that was entirely out of place here."

The fourth verbalization method is connected with the presentation of professionally significant knowledge. For example, from retro detective fiction it is possible to extract information portraying a set of goals or occupations of an institution - an organization or establishment. For example in the seventeenth century the Office of Privy Affairs was responsible for carrying out various "entertaining" ideas of the sovereign, such as: "to keep a duty log, where every day there are notes on the weather"; "the office clerks were also to be concerned with supervising the preparation of medicinal potions, which at first glance would seem to be an absurdity; but those who returned from the Polish War told how in those regions they learned to hound with poison undesirable little people." 25

In conclusion we will emphasize that the turn to retro in a cultural-historical or sociopolitical context activizes the attention of the mass recipient, stimulating him to an emotional experiencing and rational comprehension of the events described in the work. Cognitive efforts are also required of the reader for a correct reading of the "unnoticeably" accrued lingual means that had universal usage in the seventeenth century or had a wide application at the intersection of the nineteenth and twentieth centuries but are rarely used in contemporary discourse. The retro phenomenon provides the possibility to rely upon a person's cognitive system not only as a structure for processing and preserving a definite body of knowledge but also as a system reflecting through language means or other semiotic codes the way that man sees the world, what disturbs him and what he senses. This last point seems to us very significant, because retro fiction allows the reader to create conditions that stimulate emotions giving rise to sympathy and fellow feeling.

\footnotetext{
Terri Smit (Terry Smith), Osmysliaia sovremennoe kuratorstvo [Conceptualizing contemporary curatorship] ( Moscow: Ad Marginem Press,2015), p. 72.

2 Pavel B. Parshin, Territoriia kak brend: marketingovaia metafora, identiichnost' $i$ konkurentsiia [Territory as brand: marketing metaphor, identity and competition] (Moscow: MGIMO-Universitet, 2015), p. 19.

Ibid, p. 23.

George Orwell, 1984.

Aleksandr I. Filiushkin, "My ee teriaem? Vyzovy nauke istorii v XX veke,” Literaturnaia Gazeta, 17(6551), April 27 May 3, 2016, p. 16

6 Ibid.

7 Liliia V. Moiseenko, Lingvokognitivnye osnovy teorii pretsedentnosti, avtoreferat dissertatsii na soiskanie uchenoi stepeni doktora filologicheskikh nauk (Moscow: FGBOU VO MGLU, 2015), p. 16.

8 Vitalii Danilin, Chetvertaia zhertva sireni, "Retrodetektiv" Series (St. Petersburg: "Torgovo-Izdatelskii dom 'Amfora'," 2016), p. 151

9 Anna B. Khvol'son, a writer of children's literature who published her stories in the Petersburg children's magazine Zadushevnoe slovo. Her stories are based on the comics of the American artist Palmer Cox (1840-87). 1887 is also the birth year of the magazine Murzilki. Her most popular books: Rucheek. Rasskavy dlia detei iz estestvennoi istorii i detskoi zhizhni, 5th edition, verified by the author (St. Petersburg: A. F. Devrien, 1913); Druz'ia i liubimtsy. Legkie rasskazy iz zhizni zhivotnykh dlia detei malen'kogo vozrasta, 2nd edition (St. Petersburg, Moscow: T-vo M. O. Vol'f, 1904).

10 Danilin, Chetvertaia zhertva sireni, p. 151.

11 Vitalii Danilin, Dvadtsataia rapsodiia Lista, "Retrodetektiv" Series (St. Petersburg: "Torgovo-Izdatelskii dom 'Amfora'," 2016).

$12 \quad$ Ibid., p.168.
} 
Ibid.

14 Nikita A. Filatov, Poslednii vystrel kamergera, "Retrodetektiv" Series (St. Petersburg: "Torgovo-Izdatelskii dom 'Amfora,," 2016).

15 Ibid., p.42.

16 Wallachia is the historic name of the Rumanian land or country with its main city Bucharest.

17 Filatov, op. cit, p. 66.

18 Ibid., p. 275.

19 Ibid., p. 71.

20 Ibid., p.189.

${ }^{21}$ Daliia M. Truskinovskaia, Dereviannaia gramota ((St. Petersburg: “Torgovo-Izdatelskii dom ‘Amfora',” 2016), p. 122.

22 Ibid., p. 350.

23 Danilin, Chetvertaia zhertva sireni, p.124-25.

24 Ibid., p. 77-78.

25 Daliia M. Truskinovskaia, Persidskii dzhid (St. Petersburg: “Torgovo-Izdatelskii dom ‘Amfora,”, 2016), p. 6.

\title{
Способы вербализации событий
}

\section{в современном отечественном}

\section{ретродетективе}

\author{
И.А. Гусейнова \\ Московский государственный \\ лингвистический университет \\ Россия, 119034, Москва, ул. Остоженка, 38
}

\begin{abstract}
Настоящая статья посвящена исследованию современного отечественного ретродетектива. Автор отмечает специфику ретродетектива, в т.ч. его сценарность, способность к трансформации и наличие творческого потенциала. Для воссоздания событий прошлого в ретродетективе используется определенный набор лингвистических средств, прежде всего, прецедентных единии, включая прецедентные имена и феномены, а также вышедших из употребления лексических единии. В результате их комплексного применения автор ретродетектива оказывает когнитивно-прагматическое воздействие на читателя, стимулируя эмочиональную и интеллектуальную работу когнитивной системы массового реципиента.
\end{abstract}

Ключевые слова: жанр, текст, глобальный контекст, ретродетектив, ретро, литературный дискурс, событие, прецедентное имя.

Научная специальность: 17.00.00 - искусствоведение. 